\title{
INTERNATIONAL COOPERATION IN THE FIELD OF REGULATION OF AGGRESSIVE TAX PLANNING
}

Problem statement in general form and its connection with important scientific and practical tasks. The global scale of tax planning of international corporations in the world is explained so far by using it in order to maximize its own benefits by international corporations, whose activities are based on the placement of separate structural units in different countries. That is why the search for tools to limit the use of schemes for erosion of the tax base is extremely difficult - it is necessary to coordinate the efforts of various countries in order to limit the negative impact of this process on the world economy.

The problem of regulation of the tax planning of international corporations cannot be solved at the international level, since the subjects of the regulatory process are the governments of the countries that form the regulatory framework at the national level. Therefore, the optimal format is to create at the international level the basis for the functioning of national tax planning regulatory systems, to determine the direction of the regulatory process, its goals and possible means.

Analysis of recent research and publications in which the solution of this problem is initiated and on which the author relies, highlighting previously unsolved parts of the general problem to which the article is devoted. The problems of tax planning were researched in the papers of such scientists as SN. Prishva, O. Bandurko, V. Ponikarova, S. Popova, I. Apiary, V. Bychkov, V. Belous, A. Humenny, A. Molchan. At the same time, international cooperation in the field of regulation of aggressive tax planning is not researched enough, that causes interest in the implementation of scientific research on this problem.

Formulation of the objectives of the article (problem statement). The aim of the paper is to summarize the foundlings of international cooperation in the field of regulation of aggressive tax planning. To achieve this goal, the following tasks were accomplished: main initiatives in the sphere of the tax planning limitation were researched; the BEPS as the key international initiative was studied; the preconditions of implementation of the BEPS actions in Ukraine were identified.

The basic research with the substantiation of the obtained scientific results. Considering that the regulation of tax planning of international corporations is possible only with the availability of complete and comprehensive information on the actions of all companies that form the international group, a key initiative in the field of international cooperation in order to limit the negative effects of base erosion is the exchange of information for tax purposes.

Despite significant progress in automatization of the exchange of information, so far a significant number of states provide data on the actions of foreign corporations on its territory at the request of other parties, in accordance with the provisions of the 1988 Convention on Mutual Administrative Assistance in Tax Matters, which Ukraine joined 
in 2009 [1]. In addition, the regulatory framework for the exchange of tax information is also formed by bilateral agreements concluded between individual countries, and individual international articles on the avoidance of double taxation. In the case of exchanging data on the activities of enterprises that are part of a corporation, according to the regulatory framework in question, it is assumed that the competent authorities of the interested party should send a request to another country, according to which, within the time period specified in the document, relevant data will be collected and transmitted for processing. At the same time, there is a significant time lag between the transaction, that caused the submission of the request, and the provision of information about it, which significantly reduces the regulatory effectiveness of this tool.

Now, one of the key players in the coordination of the global community's efforts to counteract the effects of international corporate tax planning is the OECD, at whose initiative, in 2013, the formation of an international system for the exchange of tax information in an automatic manner began. The OECD developed a universal international document - the Common Reporting Standard (hereinafter - CRS), which any country that wants to join international cooperation in regulation of tax planning of international corporations has the opportunity to join.

The advantage of the general reporting standard is that when it is applied, each country has obligations through its financial institutions on an ongoing basis to provide, in a standardized form, information about the accounts of clients of these financial institutions to others whose residents they are. At the same time, the tax residency will be identified according to the procedure common to all participants, and the information will be provided only if the client's residency in one of the countries that participate in the agreement on automatic information exchange.

The accession of countries to the system of automatic exchange of information for tax purposes has a number of negative consequences for the banking system of the participating countries: with the country's participation in the initiative in question, financial institutions registered in its territory will not be able to refuse to transfer information, taking into account bank secrecy. According to the conclusion of the country of such obligations will adversely affect the competitiveness of banks compared with the financial institutions of those countries that have not joined the agreement.

Along with the initiative for the automatic exchange of information for tax purposes, another OECD initiative - BEPS (Base Erosion and Profit Shifting) deserves attention. BEPS, in contrast to the initiative for the automatic exchange of information, not only creates the prerequisites for countries to introduce means of countering the tax planning of international corporations, but also determines what they may be. The main advantage of BEPS is the concreteness of this document: it contains 15 reasonable actions for solving the problem of erosion by international corporations of the tax base.

BEPS Action 1. Addressing the Tax Challenges of the Digital Economy. The purpose of the first initiative is to identify key obstacles to the application of existing tax rules for companies operating in the field of digital technologies, and as a result to offer alternatives to solve existing problems.

An example of the effectiveness of this initiative is Amazon's change in tax practice on May 1, 2015: the company switched to paying taxes directly in the countries where 
operations are carried out, instead of "conducting" all operations through Luxembourg, the tax rate in which is low. In April 2016, a similar decision was made by Facebook [2].

BEPS Action 2. Neutralizing the Effects of Hybrid Mismatch Arrangements. This initiative proposes changes to the provisions of the OECD Model Convention regarding the use of hybrid financial instruments. The main activities to be implemented under this initiative include: amendments to the OECD Model Convention on the restriction of the use of benefits under the Agreements on the avoidance of double taxation in situations that lead to abuse; development of provisions of national legislations that will counteract the complete release at the level of the recipient of income, for which tax deductions are applied; development of provisions of national legislations that would limit the application of tax deductions to payments that are not taxable at the level of the recipient of income or are not subject to taxation in accordance with the tax rules of controlled foreign companies; the development of regulations governing the situation where more than one country claims to use the measures indicated above in any operation [3].

BEPS Action 3. Designing Effective Controlled Foreign Company Rules. The rules of "controlled foreign companies" are relevant in the framework of the BEPS project, as they are designed to counteract the withdrawal of profits of resident companies to the level of subsidiaries located in low-tax jurisdictions. In accordance with the Plan, in addition to the fact that these rules provide for the taxation of profits in the country of residence of the ultimate parent company, they also have a positive effect on taxation in the country of the source of income, since they limit the transfer of profits in lowtax jurisdictions.

Now, of the 85 states that are official participants of the BEPS, only 30 have implemented initiative 3 . This is due to the fact that the taxation of controlled foreign companies is very complex and requires numerous negotiations at the international level [4].

The main obstacle to the implementation of this initiative is the lack of information about controlling and controlled companies that can be used for control. First of all, for the implementation of this initiative in Ukraine, it is necessary not only to make relevant changes to the legislation of Ukraine and the treaties on avoidance of double taxation, but also to provide an effective mechanism for sharing information, since it is possible to control the information provided by the taxpayer only if there is an alternative source receiving. Thus, today the prospect of introducing such measures in Ukraine is ambiguous, since limited administrative resources and technical capabilities will not allow implementing all the activities that are necessary to benefit from this step.

BEPS Action 4. Limiting Base Erosion Involving Interest Deductions and Other Financial Payments. Action 4 provides recommendations on best practices for developing rules to combat base erosion using interest and other economically equivalent payments. Focus in action 4 is on using debt to generate excessive interest deductions for all types of debt [5].

Current problems mainly concern preferential regimes, for which there is a risk that they will be used for artificial erosion of profits, as well as a lack of transparency due to 
certain norms. Now on the agenda for action are the following: an analysis of regimes related to intellectual property, the exchange of information about clarification, the process of revising preferential regimes and the problems of determining relevant jurisdiction.

BEPS Action 5. Peer review and monitoring. In the context of transparency, a scheme was also agreed upon, which includes all explanations that could lead to problems on BEPS in the absence of a mandatory spontaneous exchange. This scheme covers six categories of clarification: explanations related to preferential treatment; international unilateral pricing transactions for tax purposes or other unilateral explanations of transfer pricing; explanations for downward revenue adjustments; explanations regarding permanent missions; clarification on dummy diagrams [6].

BEPS Action 6. Preventing the Granting of Treaty Benefits in Inappropriate Circumstances. Action 6 so far is based on the development of model clauses of the agreement and recommendations on draft internal rules to prevent the granting of tax privileges in inappropriate circumstances. The document also contains explanations that tax agreements are not intended to be used for causing double taxation. It also defines the tax policy criteria that countries generally need to consider before signing a tax agreement with another country [7].

BEPS Action 7. Preventing the Artificial Avoidance of Permanent Establishment Status. According to this action, the definition of the term "permanent establishment" should be revised in order to exclude cases of abuse of the "independent agent" rules, as well as structures involving commissioners and artificially separating activities to meet the requirements, allows obtaining the benefits provided for activities [8].

BEPS Action 8-10. Financial transactions. According to these initiatives, it is planned to supplement the rules governing transfer pricing (TC) with provisions that counteract the reduction of the taxable base by transferring intangible assets within the group. The expected result of this initiative is to introduce changes in the OECD Recommendations, as well as in the OECD Model Convention.

In addition, it is planned to supplement the $\mathrm{TC}$ rules with measures that counteract the reduction of the tax base as a result of the transfer of excess risks or the distribution of capital within the group, especially regarding artificial transfer of profits as a result of taking contractual risks or providing capital. It is necessary to develop measures that would ensure the conformity of the income received and the value produced.

BEPS Action 11. Measuring and Monitoring BEPS. Action 11 of BEPS aims to find ways to track the scale and economic impact of base blur. This action differs from other actions in that it is aimed at supporting the development of the BEPS project and is not aimed at countering the erosion of the base itself. The OECD recognizes that it is still difficult to measure the results of the implementation due to the limited available data sources and the fact that any indicator can only give a general conclusion [9].

BEPS Action 12. Mandatory disclosure rules. It is intended to develop recommendations on the mandatory disclosure of information on transactions that are carried out for tax purposes, regimes or structures, taking into account the costs for tax authorities and businesses, as well as the experience of other countries in implementing these measures. 
Tax planning schemes of minority corporations are subject to detailed study. Under this initiative, the concept of "tax benefit" should be analyzed, and model agreements on the exchange of information on international tax schemes between tax authorities should be developed. The predictable outcome of this initiative is recommendations for changes in the provisions of national legislations.

BEPS Action 13. Transfer Pricing Documentation and Country-by-Country Reporting. Tax authorities often find it difficult to understand the full value chain, which leads to difficulties in applying the standard according to which prices under contracts between related parties should be the same as those established between unrelated persons.

BEPS Action 14. Making Dispute Resolution Mechanisms More Effective. This initiative provides for the development of a mechanism for resolving disputes related to the use of agreements, such as the absence of provisions on arbitration of disputes, as well as the possibility of denying access to this procedure and arbitration proceedings [10].

BEPS Action 15. Develop a multilateral instrument. This initiative is aimed at the speedy implementation of the above points of the Plan. Thus, it is proposed to develop a multilateral agreement to amend bilateral agreements to ensure an innovative approach to international taxation.

Action 15 is associated with the frequent need to make changes to double tax treaties and the complexity of this process. To simplify this procedure the MLI was developed, which is a unique mechanism for the signatories of this protocol to simultaneously amend all conventions on the elimination of double taxation, and not each of them. To apply MLI, a country must submit a special application to the OECD, which will indicate which provisions and in which country the country wants to change in transactions.

The conclusions of this study and the prospects for further research in this direction. In our opinion, for the actual implementation of initiatives proposed by the OECD, the use of tax planning schemes by international corporations will become much problematic, and the amount of taxes that will be paid will be much higher. In this case, the prerequisite for the effectiveness of BEPS is the actual introduction of changes and the adoption of new regulatory acts to combat the tax planning of international corporations.

Economically developed countries have come a long way in countering the reduction of base enterprises, their regulatory and legal framework is more in line with modern realities than the laws of developing countries or economics in transition. At the same time, the problem of tax planning of international corporations is extremely relevant for such countries, since they are also involved in the process of internationalization of world economic relations. Thus, the ability to implement only separate elements of BEPS, preparing a regulatory framework for the further implementation of other initiatives, can be considered an effective practice.

\section{References}

1. Convention on Mutual Administrative Assistance in Tax Matters. URL: http://www.oecd.org/ctp/ exchange-of-tax-information/convention-on-mutual-administrative-assistance-in-tax-matters.htm.

2. Addressing the Tax Challenges of the Digital Economy, Action 1. 2015 Final Report. URL: http://www.oecd.org/ctp/addressing-the-tax-challenges-of-the-digital-economy-action-1-2015-finalreport-9789264241046-en.htm. 
3. Neutralising the Effects of Hybrid Mismatch Arrangements. Action 2. URL: http://www.keepeek.com/Digital-Asset-Management/oecd/taxation/neutralising-the-effects-of-hybridmismatch-arrangements-action-2-2015-final-report_9789264241138-en\#.WRH7HdLyiUk.

4. Designing Effective Controlled Foreign Company Rules. Action 3. URL: http://www.keepeek.com/ Digital-Asset-Management/oecd/taxation/designing-effective-controlled-foreign-company-rules-action3-2015-final-report_9789264241152-en\#.WRH8R9LyiUk.

5. Limiting base erosion involving interests, deductions and other financial payments. Action 4. URL: http://www.oecd.org/tax/beps/limiting-base-erosion-involving-interest-deductions-and-other-financialpayments-action-4-2016-update-9789264268333-en.htm.

6. BEPS Action 5 on Harmful Tax Practices: Transparency Framework. URL: https://www.oecd.org/ tax/beps/beps-action-5-harmful-tax-practices-peer-review-transparency-framework.pdf.

7. The principal purpose test in tax treaties under BEPS 6. URL: http://www.ey.com/Publication/ vwLUAssets/EY-the-principal-purpose-test-in-tax-treaties-under-BEPS-6/\$File/EY-the-principalpurpose-test-in-tax-treaties-under-BEPS-6.pdf.

8. Preventing the Artificial Avoidance of Permanent Establishment Status, Action 7. 2015 Final Report. URL: http://www.oecd.org/ctp/preventing-the-artificial-avoidance-of-permanent-establishment-statusaction-7-2015-final-report-9789264241220-en.htm.

9. Mandatory Disclosure Rules. Action 12. URL: http://www.oecd.org/tax/mandatory-disclosurerules-action-12-2015-final-report-9789264241442-en.htm.

10. Making dispute resolution mechanism more effective Action 14. URL: http://www.oecd.org/ctp/ making-dispute-resolution-mechanisms-more-effective-action-14-2015-final-report-9789264241633-en. htm.

\section{Summary}

Melnyk Yu. O. International cooperation in the field of regulation of aggressive tax planning. Article.

The article is devoted to the research of international cooperation in the field of regulation of aggressive tax planning. Main initiatives in the sphere of the tax planning limitation were researched, the BEPS as the key international initiative was studied and the preconditions of implementation of the BEPS actions in Ukraine were identified.

Key words: BEPS, tax planning, Common Reporting Standard, international corporation.

\section{Анотація}

Мельник Ю. О. Міжнародне співробітництво в галузі регулювання агресивного податкового планування. - Стаття.

Стаття присвячена дослідженню міжнародного співробітництва в галузі регулювання агресивного податкового планування. Досліджено основні ініціативи в сфері обмеження податкового планування, вивчені BEPS як ключова міжнародна ініціатива і визначено передумови реалізації заходів BEPS в Україні.

Ключові слова: BEPS, податкове планування, Common Reporting Standard, міжнародна корпорація.

\section{Аннотация}

Мельник Ю.О. Международное сотрудничество в области регулирования агрессивного налогового планирования. - Статья.

Статья посвящена исследованию международного сотрудничества в области регулирования агрессивного налогового планирования. Исследованы основные инициативы в сфере ограничения налогового планирования, изучены BEPS как ключевая международная инициатива и определены предпосылки реализации мероприятий BEPS в Украине.

Ключевые слова: BEPS, налоговое планирование, Common Reporting Standard, международная корпорация. 